\title{
UNA IMAGEN EN LA PROSA ENSAYISTICA DE ALFONSO REYES
}

El Alfonso Reyes humanista, investigador y crítico literario, teórico de la literatura, se complementa con un Alfonso Reyes creador de la palabra viva, poeta y artista de la prosa ${ }^{1}$. Aun en sus trabajos de erudición y en medio de su prosa más expositiva, reluce esta quintaesencia poética. Pensador perspicaz en el plano lógico, al mismo tiempo, como poeta esencial, tiende a pensar por imágenes y a organizar sus pensamientos en el ensayo informal según estructuras artísticas y extralógicas. Hasta las imágenes que iluminan su prosa ensayística parecen obedecer a un sistema artístico inconsciente pero perfectamente coherente.

\section{El "espectro alfonsino"}

Hay varias perspectivas desde las cuales puede acercarse el estudioso a las imágenes de la prosa de Alfonso Reyes en el sentido estilístico. Una de las más sorprendentemente reveladoras nos muestra toda una serie de imágenes que parecen seguir una ordenación estética, orgánica y dinámica, de procesos que llamaremos explosión, irradiación, reverberación, refracción, irisación y ondulación. Es una configuración íntegra, una serie continua en que una imagen se resuelve en otra, de matiz en matiz, como formando un "espectro" de matices o imágenes: daremos a todo este proceso el nombre de "espectro alfonsino", pues, según creemos, son procesos imaginísticos fundamentales que fluyen por la visión artística total de don Alfonso. En el presente artículo sólo consideraremos la primera de estas imágenes.

\section{Explosión}

Entre estas imágenes tan amplias como significativas, una de las más impresionantes es la que llamaremos la imagen de explosión o imagen explosiva.

1 Para el presente artículo he aprovechado materiales de la tesis que sustenté en la Catholic University of America, en cumplimiento parcial de los requisitos del doctorado en Filosofía y Letras (Patterns of image and structure in the essays of Alfonso Reyes), publicada por The Catholic University of America Press, Washington, D. C., $195^{8}$. 
Una clave para descubrir la significación de este tipo de imagen en la sensibilidad de Reyes, la encontramos en su breve caracterización del poema como cápsula explosiva. Hablando de las antologías como necesarios complementos de las historias literarias, Reyes sugiere concentrarse primero en las colecciones de poesías:

¿Por qué? Ante todo, por sus dimensiones más breves. Luego, por su mayor condensación estética. El poema es cápsula explosiva que junta en pequeñas dosis grande concentración de energía ${ }^{2}$.

Para Reyes, como para Benedetto Croce, el poema representa, en cierto sentido especial, la unidad artística quintaesenciada. Es una unidad de energía estética concentrada o condensada, comprimida como en una cápsula, y que luego podrá ser liberada, con efecto dinámico de explosión, para fertilizar o enriquecer la imaginación o sensibilidad de quien lee el poema con ondas y ritmos de sucesivas impresiones estéticas. La "explosión" es, pues, una experiencia creadora, recreadora y fertilizadora en el nivel estético. En un nivel material, las explosiones de un motor son el elemento dinámico que lo pone en marcha. La explosión es elemento del dinamismo de la vida, donde la aparente destrucción conduce a una nueva creación y a una nueva energía propulsora. Así es también en el nivel estético-verbal del poeta, quien siente, no el mero equilibrio o contraposición estática de las imágenes, sino el dinámico flujo e interrelación que sigue a sus ritmos de concentración y dispersión, a sus movimientos culminantes y a sus "explosiones". Para Reyes, el ensayo podrá ser poema o desempeñar la misma función que el poema, análogo a la glosa de Eugenio d'Ors o la greguería de Ramón Gómez de la Serna, que funden las funciones discursiva y poemática de la prosa en breves unidades de dimensiones sumamente flexibles.

Véase, además, la exposición que hace Reyes en $E l$ deslinde de la explosión como principio que está en la base del proceso creador, siguiendo líneas bergsonianas ${ }^{3}$, e incluyendo su aplicación literaria:

La explosión literaria hace saltar los tabiques, y es así cómo la literatura realiza un ajuste "intensivo"4.

La explosión está en el corazón del proceso verbal, como agente que convierte el pensamiento en acción mediante la voluntad:

La cápsula verbal no sólo encierra aromas de intelección, sino también explosivos de intención... En el campo ético y social, por

2 "Teoría de la antología", en La experiencia literaria, $2^{\mathrm{a}}$ ed., Buenos Aires, 1952, p. 112.

3 El deslinde, México, 1944, pp. 326-327.

4 Ibid., p. 211. 
ejemplo, la intención irradiada por la palabra impulsa un juicio o una acción... ${ }^{5}$

En su nivel más básico, la palabra, sin contenido semántico específico, es pura exuberancia o explosión, tal como la vemos en la vaga exclamación lírica o en la palabra auditiva asemántica, bautizada por don Alfonso con el nombre de jitanjáfora:

La jitanjáfora pura es de carácter popular, y muchas veces infantil... Ignora sus propias virtudes, y sube sola hasta la superficie del lenguaje como una burbujilla del alma. Muy bien puede ser una explosión individual. .. ${ }^{6}$

Por otro lado, la explosión se presenta como típica manifestación del proceso creador de la naturaleza, en esta asimilación de la flor con el poema, a propósito de Calderón de la Barca:

En las cápsulas explosivas de sus décimas, el teólogo poeta, venido al mundo cuando el rosal de nuestra habla literaria ha dejado reventar ya todos sus capullos, logra concentrar vastas especies universales $^{7}$.

El mismo aspecto explosivo del proceso creador artístico se ve en la expresión poética de Enrique González Martínez, esta vez con una dimensión astronómica:

El riesgo es que el poeta así dotado consienta en permanecer pasivo; en dejar que los versos crucen por la nebulosa de su alma, sin hacer de su parte nada porque esa misma nebulosa se condense y brote una estrella. Tal obra de condensación comenzó por fortuna a tiempo en el caso de González Martínez. En Los senderos ocultos ya la nebulosa se halla animada de una fuerte rotación propia, y todos los puntos del alma están irisados: el alma está ardiente, la estrella no tarda en brotar ${ }^{8}$.

La creación poética se ve a través de la imagen explosiva de la nebulosa que se condensa, haciendo brotar una estrella. La imagen es principalmente óptica y espacial. La condensación o compresión necesaria para dar ímpetu al proceso es la misma que se da en la cápsula explosiva, que ha pasado a ser la caracterización alfonsina del verdadero poema. El proceso de compresión o condensación

3 Ibid., p. 181. Nótese aquí una anticipación de la imagen de irradiación, que es la que sigue en la serie del "espectro".

6 "Las jitanjáforas", en La experiencia literaria, p. 166.

7 Prólogo a Trazos de historia literaria (1949), AROC [=Obras completas, México, 1955 ss.], t. 6, p. 410.

8 "Los senderos ocultos" (1912), AROC, t. 1, p. 304. 
conduce a una etapa de gestación o calentamiento marcada por la "rotación", en que "todos los puntos del alma están irisados: el alma está ardiente. .." Como efectos laterales tenemos el movimiento circular, la irisación y la ignición. Estas sugerencias imaginísticas de puras abstracciones psicológicas añaden dimensiones kinestésicas, cromáticas y térmicas al carácter básicamente óptico-espacial de la imagen. La irisación ${ }^{9}$ en este caso es el preludio visual del proceso explosivo. Quedamos suspensos, más acá de la consumación final de esta explosión presentada como inminente, cuando la estrella está a punto de brotar de la nebulosa. El empleo de una imagen astronómica da una dimensión cósmica al proceso creador del artista. La vida creadora es dinámica. Hay que pasar por una compresión y expansión, por una explosión que nos arrastre a un nuevo nivel de creatividad, para vivir de veras.

En los ejemplos anteriores se han visto varios verbos-clave que estructuran el concepto explosivo: hace saltar, reventar, brotar. Brotar y estallar son dos de los verbos explosivos de más expresividad en el léxico alfonsino. Otros verbos explosivos frecuentes son romper, disparar, estrellarse. Entre los sustantivos de frecuente valor explosivo están cápsula (explosiva), cohete y el sustantivo verbal estallido.

\section{La explosión estructurada}

Veamos cómo la imagen de explosión se infiltra en la propia estructura de fondo de un pasaje señalado por Reyes como "punto de arranque de mi prosa"10. El joven Alfonso, en su exuberancia, quería

suscitar entusiasmos, sacudir torpores y despertar, en fin, en las inteligencias... ese movimiento, esa inquietud, ese temblor que precede a las gestaciones todas; que comienza, en los seres, por ayuntar los sexos; acaba por resolverse en la alta producción intelectual, y no es sino remedo del eterno movimiento, de la eterna inquietud, del temblor eterno con que los gérmenes infinitos, calentados en la entraña laboriosa de la tierra, se hinchan primero, fecundizados, y rompen a poco el suelo, irguiendo al aire tallos que acaban en estallido de flores y frutos.

Esta imagen explosiva vincula tres niveles de experiencia: el proceso de la inspiración y creación intelectuales se confunde con las dos esferas de creación o reproducción física humana y de nacimiento y crecimiento de la vida en la planta, expresiones, todas ellas,

9 Ia imagen de irisación aquí anticipada es una de las últimas del "espectro".

10 "Alocución en el aniversario de la sociedad de alumnos de la Escuela Na. cional Preparatoria" (1907), $A R O C$, t. 1, p. 313. (Véase la nota, p. 319). 
del ritmo cósmico trascendente de la vida y la existencia en este universo.

El proceso vital en cualquiera de estos niveles comprende un ritmo de sucesivas creaciones y re-creaciones: un temblor preliminar en medio de la vaga inquietud del estado de sueño, luego un contacto fertilizador que culmina en el brote de una nueva vida, o sea en explosión creadora. Lo que estaba escondido o dormido sale a la luz en un impulso intensificado de profusión y de crecimiento. Recorre tres etapas este ritmo: $I$ ) el vago temblor, ebullición o vibración; 2) la explosión o estallido que lleva a un nuevo nivel; 3) un crecimiento creador, en dirección ascendente, desde el nuevo nivel.

Sintácticamente, este ritmo ternario de la creatividad se estructura en el movimiento ternario del párrafo, un movimiento ternario espiralizante de grupos de tres elementos que encajan uno dentro del otro.

\section{El eco explosivo}

Al final de la misma Alocución que se acaba de citar, vemos cómo la explosión podrá prolongarse e intensificarse mediante el efecto reiterativo del eco o reverberación auditiva:

Y quise también decir mi amor a la Escuela, y más que eso, mi amor a la vida. El mismo amor que cascabelea en el ruido de las pesuñas de Pan cuando van quebrando la hojarasca; el mismo que suena en las carcajadas de Anacreonte, remedando gorgoritos de vino, rumor de tazones de plata y canciones de fiestas báquicas; el mismo que fluye de los consejos de Horacio como un aroma penetrante de frutos melíferos y sazonados; el mismo que suspiraba la avena rural bajo el haya de los idilios clásicos. ¡El amor a la vida!11

Las dos primeras partes contienen efectos auditivos de gran fuerza, que llevan a una nivelación en la tercera y en la cuarta partes, primero en la esfera olfativo-gustativa, y luego de nuevo en la auditiva. Los efectos explosivos se dividen aquí en dos cadenas continuas. Las dos se orientan en la dirección del eco, y poseen una calidad fragmentaria parcial que se extiende por evocación a otros niveles de experiencia, sugiriendo en Anacreonte toda una constelación de imágenes en visión tridimensional y multiplicativa. La carcajada y el cascabeleo son típicas expresiones imaginísticas de la explosión multiplicativa que se da en el eco.

\section{Explosión destructiva y constructiva}

En la climáctica exposición explosiva de los efectos de la maldición de Tántalo, encontramos una explosión de fuerza destructiva. La imagen explosiva germinal es rudamente fisiológica: 
Tántalo insolente y punido; Tiestes vomitando a sus hijos. . ${ }^{12}$

y pone en movimiento toda una erupción de frases reiterativas que evocan la caótica destrucción provocada por la fatalidad, con sus sucesivas víctimas. Pero la destrucción no tiene la última palabra. Se trata más bien de una especie de purificación que nos prepara para concentrarnos en la sola figura casta e inspiradora de Electra. Catarsis preliminar para llegar a la exaltación e iluminación de la virtuosa y heroica Electra, para realzar el aspecto ennoblecedor de su tragedia. La imagen y enumeración explosivas han sido una fuerza negativa precipitadora de un contra-movimiento positivo. Creación, destrucción, re-creación: éste, simplemente, es el ritmo vital esencial, el ritmo de todos los seres vivos y de todos los procesos vitales. Estilísticamente, la unidad de la imagen explosiva es un dinámico mecanismo de enfoque que da fuerza pulsante al movimiento de la prosa.

\section{Polaridades negativas y positivas de la explosión}

Otra modalidad rítmica que se siente muy a menudo en el dinamismo de la explosión es la de una especie de polarización magnética, de separación negativa seguida de atracción positiva.

En el rico panorama plástico-multisensorial de los tejados de Toledo vistos desde el "Ventanillo" de Alfonso Reyes y sus compañeros Américo Castro, Antonio Solalinde y José Moreno Villa, el poeta tiene esta sensación:

En el orbe cristalino y vibrátil, voltea el alma, henchida de olvido. $\mathrm{Y}$, de pronto, estalla como cohete, da en el campanile de la Ermita y estremece frenéticamente la campana ${ }^{13}$.

La explosión sigue un nuevo ritmo ternario, subrayado por los tres verbos voltea, estalla y estremece, que corresponden a su vez al orden natural de los componentes de la sensación auditiva. El alma se zambulle en las ondas del aire y llega a identificarse con la explosión del repique de la campana. Pero primero se aleja volando, en ese éxtasis negativo que es el olvido. Entonces vuelve atraída al campanario, produciendo una explosión como de cohete. Finalmente, la sencilla explosión está seguida de un efecto repetitivo-reverberante que continúa la explosión en prolongación difusa, en eco.

El mismo ritmo ternario se reproduce en miniatura más adelante, cuando se enfoca la vista en dos pajarillos llamados Benedictine y Poussecafé:

Benedictine y Poussecafé - las dos golondrinas del Ventanilloestán, desde el amanecer, con casaca negra y peto blanco. A veces, 12 "Las tres Electras" (1908), en Cuestiones estéticas, AROC, t. 1, pp. 16-17. 13 "En el Ventanillo de Toledo" (1930), Las visperas de España, AROC, t. 2, p. 94 . 
se lanzan -diminutas anclas del aire- y reproducen sobre el cielo, con la punta del ala, el contorno quebrado, la cara angulosa de la ciudad.

Benedictine vuelve la primera, y se pone a llamar a su enamorado. Dispara una ruedecita de música que lleva en el buche. La ruedecita gira vertiginosamente, y acaba soltando unas chispas - como las del afilador- que le queman toda la garganta. Por eso abre el pico y tiembla toda, víctima de su propia canción, buen poeta al cabo.

Al fin, vuelve Poussecafé a su lado. Salta como un clown en el alambre, salta, salta. Salta sobre Benedictine; vuelve al aire. Y Benedictine sacude las plumas, y dispara otra vez la ruedecita musical que tiene en el buche ${ }^{14}$.

Una vez más, el proceso explosivo sigue un ritmo ternario que consiste en $r$ ) un vuelo de alejamiento, 2) la explosión propiamente dicha, 3) una reiteración de la explosión: todo lo cual produce una alternancia de ritmo centrífugo y centrípeto.

\section{Fuego y juego explosivos}

Otro aspecto que resalta en este ejemplo de reacción explosiva es el elemento de juego amoroso de los pájaros, que tal vez se considere como una de las expresiones simbólicas del fenómeno de la exuberancia creadora en general. La "ruedecita de música" es parte del repertorio de los símbolos amorosos, en el cual hay elementos de fuego y explosión como llamas y chispas, que nos hacen pensar, por ejemplo, en los símbolos del amor a lo divino pintado por los poetas místicos (cf. "Vuélvete, paloma" en Santa Teresa, y la "Llama de amor viva" de San Juan de la Cruz).

En la frase "víctima de su propia canción, buen poeta al cabo", se siente al pajarillo como símbolo del poeta con su exuberancia creadora en la esfera estética. Luego, el ritmo explosivo ternario se entrelaza con el ritmo ternario de la imaginística amorosa: $I$ ) el amante, 2) la amada, 3) los dos unidos que se hablan y se responden; los dos pajarillos, primer pájaro, segundo pájaro y luego los dos reaccionando mutuamente. La explosión, en su calidad de imagen estética, siempre será un proceso exuberante y revitalizador.

\section{Explosión eléctrica}

El concepto de rechazo y atracción magnéticos, visto anteriormente como preludio a la explosión, tiene su expresión más directa y literal en la forma de explosión eléctrica, con su repulsión y atracción, negativa y positiva. Esa fuerza se ve en el centro del alma humana: 
Somos acción y contemplación; somos actor y espectador; somos ánodo y cátodo, y chispa que los polos se cambian; lucha y conciliación de principios antagónicos. . Y Y esto viene a ser nuestra alma: la región de las atracciones y repulsiones, la región del rayo ${ }^{15}$.

Se presenta de nuevo un ritmo ternario, afín al del simbolismo amoroso: positivo (1) más negativo (2) produce fusión (3). El propio Reyes lo formula también en la ecuación: Creación más Crítica es Vida, en este magistral ensayo sobre lo que es la crítica.

\section{Fuerza generadora de la explosión}

Finalmente, notamos que la fuerza dinámica de la explosión tiende a poner en movimiento otros efectos, y así la imagen explosiva será una imagen germinal o generadora de otros efectos estéticos y de otras imágenes.

Véase, por ejemplo, cómo los múltiples elementos líquidos y plásticos se combinan con un efecto explosivo auditivo:

El parque... es, como suele decir la gente, un sueño; un sueño en la hamaca de la naturaleza, perdido entre los regazos de las colinas. De aquel parque brota un sopor sutil que se apodera completamente de los sentidos y que, el primer día, se parece al sueño. El parque es un sueño. Por la noche, el rumor del agua, el croar rasgado de las ranas, el chirrido familiar de los grillos, suenan sobre el fondo sinfónico de los sapos. Los sapos sueltan dos campanillazos purísimos, como dos burbujas musicales que revientan entre la sombra, y fingen un tañir de cascabelillos de plata prendidos a la collera de unos bueyes sonámbulos, que araran -invisibles- en mitad de la noche ${ }^{16}$.

Aquí se funden el mundo líquido y el de los sonidos en un ambiente onírico transfusor, donde los sonidos explosivos producidos por los sapos se vuelven campanas resonantes; éstas sugieren burbujas musicales contra el fondo del cuasi-silencio, con sus sonidos de fondo más débiles, pero más constantes, y la fantasía pasa a dibujar un cuadro de cascabeles que acompañan a mitológicos bueyes sonámbulos que van arando. La explosión en medio de un ambiente de vaguedad tiende a poner en marcha una serie de sugerencias de otras impresiones sensoriales. La explosión tiende hacia la irradiación o hacia la reverberación, y veremos producirse una cadena de tales reacciones. Todas las etapas de este proceso se hallarán en la Visión de Anáhuac, polifacética evocación artística del eterno pasado mexicano.

James Willis Robb

The George Washington University,

Washington, D. C.

15 "Aristarco, o anatomía de la crítica", La experiencia literaria, p. 84.

16 "Zaldívar" (1920?), en Las visperas de España, AROC, t. 2, pp. 173-174. 